\title{
Importance of structure and density of macroalgae communities (Fucus serratus) for photosynthetic production and light utilisation
}

\author{
Thomas Binzer*, Kaj Sand-Jensen \\ Freshwater Biological Laboratory, University of Copenhagen, Helsingørsgade 49-51, 3400 Hillerød, Denmark
}

\begin{abstract}
Determination of photosynthetic production in plant communities is essential for evaluating plant growth rates and carbon fluxes in ecosystems, but it cannot easily be derived from the photosynthetic response of individual leaves or thalli, which has been the focus of virtually all previous aquatic studies. To evaluate the regulation of aquatic community production, we measured the photosynthetic production of thallus parts and entire communities of Fucus serratus (L.) of different density and spatial structure exposed to varying photon flux density and dissolved $\mathrm{CO}_{2}$ concentration. Photosynthetic production in relation to photon flux density differed considerably between entire communities and individual thallus parts. No light saturation occurred in the communities, and all photosynthetic variables such as light compensation point, efficiency of light utilisation at low light and maximum production at high light depended on community density. Therefore, while the determination of the production of individual algal thalli is useful for evaluating differences in acclimatisation and adaptation between species and stands, it is not useful for evaluating production rates for entire plants and communities. Maximum gross production of $F$. serratus followed a hyperbolic curve at increasing community density, reaching a maximum of $30 \mu \mathrm{mol} \mathrm{O}_{2}\left(\mathrm{~m}^{2} \text { ground area }\right)^{-1} \mathrm{~s}^{-1}$ at a leaf area index (LAI) of 8 to 10. Maximum net community production in the light was attained at an LAI of 6 to 8, while the maximum in a natural day-night cycle is attained at an LAI of 5 to 6 . Maximum gross production was about 3-fold lower in F. serratus communities than in terrestrial communities in forests, grasslands and crops. Manipulating F. serratus communities to a more vertical structure increased light penetration and gross production in the communities, implying that canopy structure had a profound influence on community production and that a non-optimal distribution of light is likely to be the main reason for the lower maximum gross production rates in aquatic than terrestrial plant communities.
\end{abstract}

KEY WORDS: Community production - Photosynthesis - Light distribution · Community density · Community structure $\cdot$ Macroalgae $\cdot$ Fucus serratus

\section{INTRODUCTION}

Community production has been extensively investigated in terrestrial ecology by empirical studies (Forseth \& Teramura 1986, Ehleringer \& Forseth 1990, Sassenrath-Cole 1995) and modelling approaches (Kuroiwa 1970, Barnes et al. 1990, Sands 1995). The results have shown that photosynthetic production of

*E-mail: tbinzer@fbl.zi.ku.dk leaves does not represent the behaviour of whole plants (Beyschlag \& Ryel 1998). Therefore, both the production-light response (P-I curves) of the individual leaves, and the spatial distributions of leaf biomass and light must be considered in order to explain or predict the productivity of whole plants or communities. However, measurements of photosynthetic production in aquatic macrophyte communities are surprisingly few (e.g. Van der Bijl et al. 1989, Krause-Jensen \& Sand-Jensen 1998), and studies of the environmental and plant structural features determining community 
production are virtually absent. This lack of knowledge is unfortunate because community production is an important determinant of plant growth rates, nutrient cycling, secondary production and carbon dynamics in ecosystems.

The general hyperbolic form of P-I curves is well known from measurements on terrestrial and aquatic plant leaves and algal thalli (e.g. Lüning \& Dring 1985, Sand-Jensen 1988, Markager \& Sand-Jensen 1994). The hyperbolic form implies that photons are utilised at maximum efficiency for photosynthesis in low light, while the efficiency gradually decreases with increasing light above light saturation. The efficiency of utilising incident and absorbed photons (quantum efficiency) in low light and the maximum rate of production in high light has been extensively documented for terrestrial and aquatic macrophytes (e.g. Frost-Christensen \& Sand-Jensen 1992, Enriquez et al. 1996).

Broad-scale comparisons of quantum efficiency and maximum production expressed on a dry weight basis do not reveal systematic differences between photosynthetic tissue of terrestrial and aquatic macrophytes (Enriquez et al. 1996). Nonetheless, terrestrial plant communities display much higher production rates than aquatic plant communities, suggesting that a sub-optimal spatial light distribution among the photosynthetic tissue in aquatic plant communities might be the main reason responsible for the low values (Sand-Jensen \& Krause-Jensen 1997). Additionally, both extensive light attenuation and low diffusivity of inorganic carbon in water have been proposed to represent further constraints to the production rates in dense aquatic communities (e.g. Madsen \& Sand-Jensen 1991, Carr et al. 1997).

In plant communities with multiple layers of photosynthetic tissue, the distribution of light among thallus parts has a major influence on community gross production. Because of the hyperbolic photosynthesislight relationship of individual photosynthetic elements, light must be evenly distributed for all tissue in the community to receive low photon flux densities and attain a high efficiency of light utilisation. To attain high biomass and production rates in a community, light should therefore be evenly distributed among the different layers of photosynthetic tissue (Russell et al. 1990, Ishii 1998). If this distribution is achieved, there will be an almost linear relationship between community production and incident light up to the maximum photon flux density attainable, while the individual photosynthetic elements studied alone become light saturated at much lower photon flux density (Ceulemans \& Saugier 1991, Ruimy et al. 1995).

A common canopy structure in terrestrial plants conducive to efficient light utilisation and high community production is a vertical leaf orientation at high light in the upper part of the canopy and a horizontal leaf orientation at low light in the lower part of the canopy (Russell et al. 1990, Myers et al. 1997). A vertical leaf orientation, characterised by a high leaf angle $(\delta$, angle between the sun and the normal to the leaf surface) relative to the incoming photon flux density $\left(I_{0}\right)$, will markedly reduce the photon flux density received per unit of leaf surface area $\left(I_{\mathrm{L}}=I_{0} \cos \delta\right)$ by distributing incident light at the planar surface over a large leaf surface. Furthermore, the existence of many small leaves, and the clumped dispersion of leaves, acts to increase bending, scattering and transmission of light in the canopy, thereby facilitating a more even distribution of light among the photosynthetic tissue (Oker-Blom \& Kellomäki 1983).

Development of an optimal and well-defined structural distribution of leaf density and leaf orientation in terrestrial canopies requires stiff leaves and strong structural support from petioles, twigs and stems. The same option does not exist in aquatic canopies because aquatic macrophytes have flexible tissue to withstand the strong drag and shear forces of moving water (Koehl 1983, Gaylord et al. 1994). Aquatic macrophytes are therefore unable to form a similar welldefined spatial distribution of photosynthetic tissue in order to optimise light distribution and community photosynthesis.

To test the importance of community structure for the production-light relationship of aquatic communities we compared the P-I curves for individual thalli of the marine macroalgae Fucus serratus (L.) with P-I curves of Fucus communities of different density and physical orientation. We also compared the maximum production rates and the production-light relationships of Fucus communities with those of terrestrial communities. Finally, we tested the importance of inorganic carbon supply for the community production rates.

\section{MATERIALS AND METHODS}

Fucus serratus was collected by hand at a shallow boulder reef in Aalsgaarde on the northern coast of Zealand, Denmark, in April 2000. The selected specimens were 30 to $40 \mathrm{~cm}$ long. Prior to experiments they were kept for a maximum of $4 \mathrm{~d}$ in large buckets of aerated seawater at $16^{\circ} \mathrm{C}$. No effect of storage was seen on the production rates. To resemble natural communities, epiphytes were left on the tissue, but the healthiest looking and least epiphytised specimens were selected for experiments.

Photosynthetic production of thallus pieces. A closed cylindrical glass chamber $(78 \mathrm{ml})$ was used for measuring the production-light response of thallus 
pieces taken from the upper, middle and lower part of the specimens. Measurements were performed in filtered natural seawater from the collection site, which were kept close to $16^{\circ} \mathrm{C}$ by means of a constant-temperature cooling jacket surrounding the photosynthesis chamber. To further minimise heating of the chamber at high light, a petri dish containing $1 \mathrm{~cm}$ of water in depth was inserted between the light source and the chamber to absorb long-wave thermal radiation.

Algae were fixed horizontally on a plastic net in the chamber, and a magnetic stirrer bar assured stirring. Incident light on the thallus surface was supplied from a $100 \mathrm{~W}$ halogen lamp. The maximum photosynthetic photon flux density (PPFD) was set at $1540 \mu \mathrm{mol}$ photon $\mathrm{m}^{-2} \mathrm{~s}^{-1}$, and variable photon fluxes $(0,5,30,90$, $380,750 \mu \mathrm{mol}$ photon $\mathrm{m}^{-2} \mathrm{~s}^{-1}$ ) were obtained by inserting neutral density filters between the light source and the chamber. The temperature in the photosynthesis chamber was continuously recorded (Picolog, TC-08, Picotech) in order to avoid measurements during lightdark switches with temperature changes reaching 0.5 to $0.7^{\circ} \mathrm{C}$ or, if necessary, to be able to correct for temperature sensitivity of the electrode $\left(3 \%{ }^{\circ} \mathrm{C}^{-1}\right)$. During production measurements in high light, temperature changes were less than $0.1^{\circ} \mathrm{C} \mathrm{min}-1$ and had no significant influence on the calculated production rates.

Photosynthetic production and respiration were measured as oxygen evolution and consumption rates by means of a Clark-type microsensor (Revsbech \& Jørgensen 1986). The electrode output was logged on a computer using an analogue-digital converter (Picolog, ADC-12). Net production (NP) in the light and respiration $(R)$ in the dark were calculated from the linear slope of the curve describing oxygen concentration versus time when constant rates had been attained. Linear regressions of oxygen concentration versus time were always highly significant $\left(\mathrm{r}^{2}>0.99\right)$ in all measurements. Gross production (GP) was calculated as the sum of net production and dark respiration $(G P=$ $N P+R$ ), assuming that dark respiration continued unaltered in the light. Measurements were expressed per unit of thallus surface area, measured immediately following the experiments, with a surface area meter (Li-3000, Li-Cor).

The P-I curves were characterised by the following photosynthesis parameters. The photosynthetic efficiency at low light $(\alpha)$ was determined as the initial linear slope between photosynthetic production and photon flux density during light limitation. The linear production-light relationship in low light was also used to calculate the light compensation point $\left(I_{\mathrm{C}}=R \alpha^{-1}\right)$ at which gross production and respiration are of equal magnitude and net oxygen exchange is 0 . The maximum rate of gross production $\left(G P_{\max }\right)$ was determined at light saturation $\left(I_{\text {sat }}\right)$, the onset of which was estimated as $G P_{\max } \alpha^{-1}$. The same terminology and methodology were used to determine the photosynthetic parameters for entire communities. The subscripts $t$ and $c$ are used to distinguish between the photosynthetic parameters of single thalli and communities, respectively.

Photosynthetic production in communities. The photosynthetic production of communities was measured in a $28 \mathrm{l}$ chamber using the same principles as for thallus pieces. Intact specimens of Fucus were placed in the photosynthesis chamber and P-I relations were determined under a wide range of thallus densities gradually increasing from 0.8 to 18 LAI (leaf area index). LAI is the leaf/thallus surface area (1-sided) relative to the ground surface area. Results for intact Fucus specimens were compared with those obtained by cutting the individuals into 15 to $20 \mathrm{~cm}$ long pieces and placing them in a vertical position in the chamber to obtain a more homogeneous light distribution between the different thallus pieces.

The photosynthesis chamber was immersed in a thermostatically controlled aquarium (200 l) to maintain constant temperature. Stirring was ensured by 2 submersible pumps and the stirring rod of the oxygen electrode. The 2 pumps produced a unidirectional flow, keeping the plants in a position resembling natural habitats with currents. Uniform mixing of water in the chamber, measured by injecting a pulse of oxygen-depleted water in the chamber, was achieved within $30 \mathrm{~s}$.

The light source was a $400 \mathrm{~W}$ mercury lamp yielding a maximum PPFD of $1600 \mu \mathrm{mol}$ photon $\mathrm{m}^{-2} \mathrm{~s}^{-1}$. Variable PPFDs of $0,30,70,160,340$ and $740 \mu \mathrm{mol}$ photon $\mathrm{m}^{-2} \mathrm{~s}^{-1}$ were obtained by inserting neutral filters between the light source and the photosynthesis chamber. All experiments were performed at $16 \pm 0.2^{\circ} \mathrm{C}$, and there was no significant change in temperature during light-dark switches. Dissolved oxygen was measured with a temperature-compensated macroelectrode (YSI 5905), the signal from which was registered every $5 \mathrm{~s}$ and averaged and logged every $1 \mathrm{~min}$ on a datalogger. The oxygen concentration was continuously followed on a pen recorder. Production rates were measured when the rate of oxygen change had remained constant for at least $10 \mathrm{~min}$.

The thallus surface area (1-sided) was closely linearly related to the fresh weight of several Fucus serratus specimens $\left(16.5 \pm 0.5[95 \% \mathrm{CL}] \mathrm{cm}^{2} \mathrm{~g}^{-1}\right.$ fresh $\mathrm{wt}, \mathrm{n}=6$ ). Routine measurements of fresh weight were used to calculate thallus surface area and LAI for every experiment. Light absorptance by the thalli was estimated from the transmittance of a perpendicular light beam, assuming negligible reflectance when incident radiation is received at right angles. 
The relationship between maximum community gross production $\left(G P_{\mathrm{c}, \max }\right)$ and increasing community density (LAI) was described by the hyperbolic expression:

$$
G P_{\mathrm{c}, \max }=\frac{\beta \cdot \mathrm{LAI} \cdot G P_{\mathrm{c}, \mathrm{MAX}}}{\left(G P_{\mathrm{c}, \mathrm{MAx}}{ }^{2}+[\beta \cdot \mathrm{LAI}]^{2}\right)^{\frac{1}{2}}}
$$

where $\beta$ is the initial slope of $G P_{\mathrm{c}, \max }$ versus LAI and $G P_{\mathrm{C}, \mathrm{MAX}}$ is the maximum attainable gross production at high LAI. Maximum community net production $\left(N P_{\mathrm{c}, \mathrm{max}}\right)$ was fitted to a similar expression by subtracting community respiration $\left(R_{\mathrm{c}}\right)$ from maximum community gross production $\left(G P_{\mathrm{c}, \max }\right)$.

The maximum production theoretically obtainable with an even distribution of light was calculated as:

$$
G P_{\mathrm{c}, \max }=\mathrm{LAI} \cdot G P_{\left(I_{0} / \mathrm{LAI}\right)}
$$

where $G P_{(I / \mathrm{LAI})}$ is the gross production of a single thallus piece at a photon flux density of $I_{0} \mathrm{LAI}$, which can be obtained from measurements on single thallus pieces.

Effect of inorganic carbon supply. The possibility of carbon limitation of community production in high light was tested for 3 community densities (LAI 2.6, 9.3 and 12.3). Carbon availability was gradually increased by stepwise reduction of $\mathrm{pH}$ in the chamber from 8.4 to 8.2 and 8.0 to 7.6 , thereby increasing the concentration of readily usable $\mathrm{CO}_{2}$ from 8.4 to $62 \mu \mathrm{M}$, which is equivalent to 0.4 to $2.8 \%$ of the total inorganic carbon concentrations (DIC: $\mathrm{CO}_{2}+\mathrm{HCO}_{3}{ }^{-}+\mathrm{CO}_{3}{ }^{2-}$ ). Different LAIs were chosen because $\mathrm{CO}_{2}$ exchange with the surrounding water can be expected to be lower when communities become denser.

\section{RESULTS}

\section{Production-light relationships of thallus pieces}

P-I curves differed among thallus pieces taken from the 3 different strata in the Fucus serratus thallus (Fig. 1). The mean photosynthetic efficiency at low light $\left(\alpha_{\mathrm{t}}\right)$ ranged from 0.058 to $0.076 \mathrm{~mol} \mathrm{O}_{2} \mathrm{~mol}^{-1}$ incident photon and tended to increase from the upper to the lower part of the canopy, although not significantly (Fig. 2). Mean $\alpha_{\mathrm{t}}$ was $0.064 \mathrm{~mol} \mathrm{O}_{2} \mathrm{~mol}^{-1}$ incident photon. As the mean thallus absorptance $(A)$ was $0.92 \pm$ 0.03 (95\% CL, $\mathrm{n}=30$ ), individual $F$. serratus thalli had a mean quantum efficiency $\left(\theta=\alpha_{\mathrm{t}} A^{-1}\right)$ of about $0.07 \mathrm{~mol}$ $\mathrm{O}_{2} \mathrm{~mol}^{-1}$ absorbed photon.

The mean light-saturated gross production $\left(G P_{\mathrm{t}, \max }\right)$ was significantly higher in the upper part of the canopy $\left(6.8 \pm 1.1 \mu \mathrm{mol} \mathrm{O} \mathrm{O}^{-2} \mathrm{~s}^{-1}, 95 \% \mathrm{CL}\right.$, Fig. 3) than in the lower part $\left(4.4 \pm 0.9 \mu \mathrm{mol} \mathrm{O} \mathrm{O}_{2} \mathrm{~m}^{-2} \mathrm{~s}^{-1}\right)$.

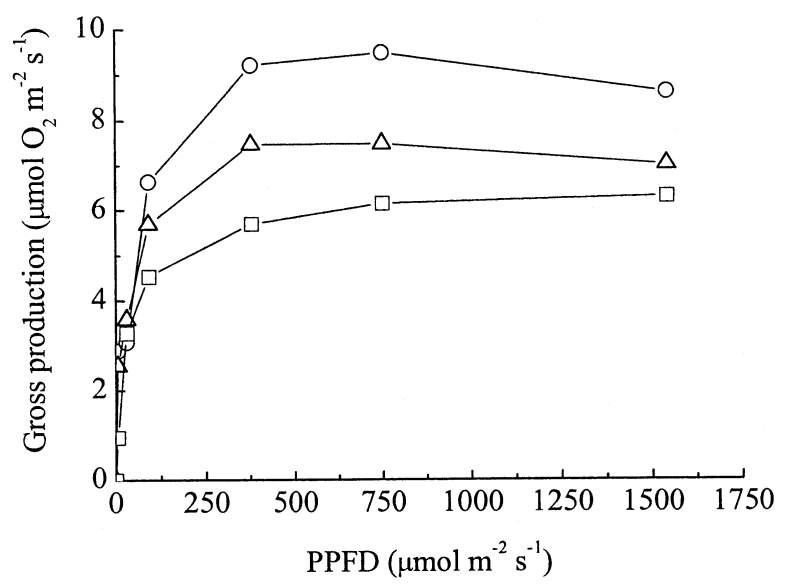

Fig. 1. Gross production as a function of photosynthetic photon flux density (PPFD) for thalli from the upper (O), middle $(\Delta)$ and lower $(\square)$ strata in Fucus serratus. Mean values of 5 experiments

The light compensation point of photosynthesis did not change with position in the thallus and had a mean value of $22 \mu \mathrm{mol}$ photon $\mathrm{m}^{-2} \mathrm{~s}^{-1}$. The onset of light saturation $\left(G P_{\mathrm{t}, \max } \alpha_{\mathrm{t}}{ }^{-1}\right)$ ranged from 100 to $160 \mu \mathrm{mol}$ photon $\mathrm{m}^{-2} \mathrm{~s}^{-1}$, with a tendency of lower $I_{\text {sat }}$ values in the lower part of the algal canopy (range 32 to $140 \mu \mathrm{mol}$ photon $\mathrm{m}^{-2} \mathrm{~s}^{-1}$ ) than in upper part of the canopy (range 115 to $185 \mu \mathrm{mol}$ photon $\mathrm{m}^{-2} \mathrm{~s}^{-1}$ ), although the difference was not significant. Thalli were all fully light saturated at $400 \mu \mathrm{mol}$ photon $\mathrm{m}^{-2} \mathrm{~s}^{-1}$ and showed no significant photoinhibition up to the maximum PPFD tested (1600 $\mu$ mol photon $\left.\mathrm{m}^{-2} \mathrm{~s}^{-1}\right)$.

\section{Production-light relationships in communities of different density}

Gross community production increased with photon flux density in communities of different density (LAI: 3.0 to 13.8 ) and showed no sign of saturation at the

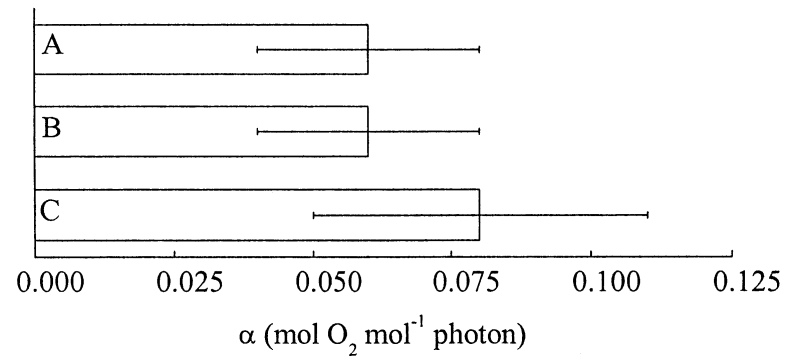

Fig. 2. Photosynthetic efficiency at low light $(\alpha)$ for thalli from the upper (A), middle (B) and lower strata (C) in Fucus serratus. Mean values $\pm 95 \% \mathrm{CL}$. Differences are not significant between the 3 strata (ANOVA, $\mathrm{p}>0.05, \mathrm{n}=15$ ) 


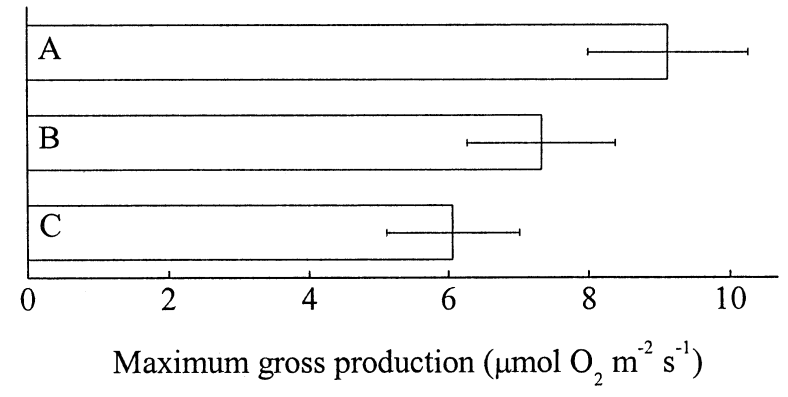

Fig. 3. Light-saturated gross production of thalli from the upper (A), middle (B) and lower strata (C) in Fucus serratus. Mean values $\pm 95 \%$ CL. Gross production was significantly higher in the upper than in the lower part of the thallus (ANOVA/Tukey-test, $\mathrm{p}<0.05, \mathrm{n}=15$ )

highest photon flux density of $1600 \mu \mathrm{mol}$ photon $\mathrm{m}^{-2} \mathrm{~s}^{-1}$ (Fig. 4). The light compensation point was markedly higher for communities (67 to $175 \mu \mathrm{mol} \mathrm{m} \mathrm{m}^{-2} \mathrm{~s}^{-1}$ ) than for thallus pieces $\left(22 \mu \mathrm{mol} \mathrm{m} \mathrm{m}^{-2} \mathrm{~s}^{-1}\right)$ as self-shading in communities increased the role of respiration rates (Table 1). Maximum community gross production $\left(G P_{c, \max }\right)$ in high light increased as LAI increased from 3.0 to 13.8 , but the rate of increase gradually declined at high LAIs (Table 1, Fig. 5). The photosynthetic efficiency of the community in low light $\left(\alpha_{c}\right)$ showed a similar behaviour, gradually increasing from 0.031 to $0.072 \mathrm{~mol} \mathrm{O}_{2} \mathrm{~mol}^{-1}$ incident photon as communities became denser and absorbed more light (Table 1). Photosynthetic efficiency in dense communities is likely to be close to the quantum efficiency $(\theta)$ of the thalli because most incident photons were absorbed in the communities. Maximum gross production in high light increased almost linearly with LAI at low algal densities, but increased at a lower rate when LAI exceeded 6 (Fig. 5). The relationship between community production and LAI fitted a hyperbolic function (Eq. 1), predicting a linear relationship of $5.1 \pm 0.5 \mu \mathrm{mol}$ $\mathrm{O}_{2} \mathrm{~m}^{-2} \mathrm{~s}^{-1} \mathrm{LAI}^{-1}\left(\mathrm{r}^{2}=0.83\right.$, Fig. 5) at low community density $(\beta)$ and a maximum community production per

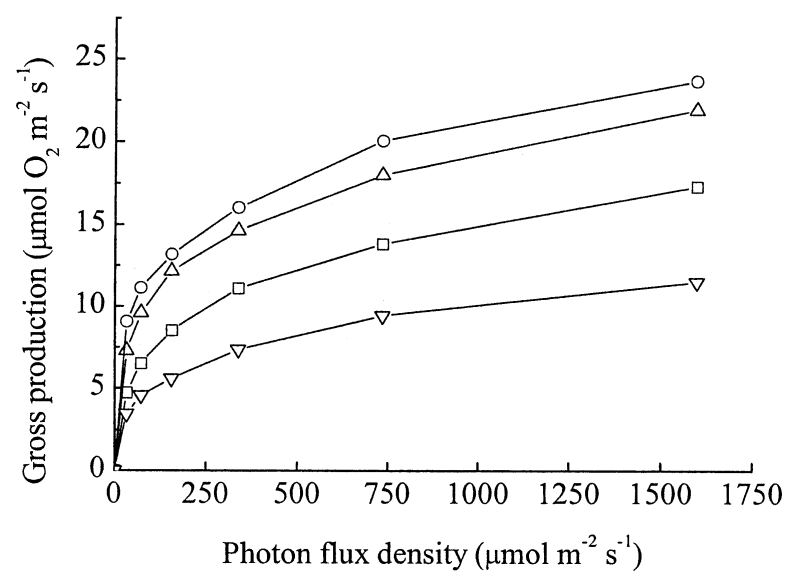

Fig. 4. Gross production as a function of photosynthetic photon flux density in 4 Fucus serratus communities of different density. Leaf area indices (LAIs) of $3.1(0), 6.3(\Delta), 8.9(\square)$ and $13.8(\nabla)$

ground area of $29.9 \pm 1.5 \mu \mathrm{mol} \mathrm{O}_{2} \mathrm{~m}^{-2} \mathrm{~s}^{-1}$. Community respiration $\left(R_{\mathrm{c}}\right)$ increased in direct proportion to LAI $\left(R_{\mathrm{C}}=0.90 \pm 0.04 \mu \mathrm{mol} \mathrm{O} \mathrm{O}^{-2} \mathrm{~s}^{-1} \mathrm{LAI}^{-1}, \mathrm{p}<0.0001\right.$, $\left.\mathrm{r}^{2}=0.81\right)$ corresponding to a constant respiration rate per unit of thallus surface area independently of community density (Fig. 5). In consequence, net community production $\left(N P_{\mathrm{c}}\right)$ reached a maximum at a community density when LAI was between 8 and 10 and declined above this threshold (Fig. 6). Because of the hyperbolic relationship between gross community production and community density, gross production per unit of thallus surface area declined exponentially with LAI (Fig. 7).

\section{Gross community production in optimal light climates}

Gross community production can be predicted for an optimal distribution and utilisation of incident light (Eq. 2) by assuming that light is evenly distributed

Table 1. Photosynthetic parameters for thallus pieces and communities of varying leaf area index (LAI). Note the increasing $I_{c}$ values in the communities as LAI increases. The maximum gross production theoretically obtainable, $G P_{\max }$, was calculated based on a situation of optimal distribution and utilisation of light in the community (Eq. 2). Not sat.: community was not saturated at maximum photosynthetic photon flux density

\begin{tabular}{|c|c|c|c|c|c|c|}
\hline \multirow[b]{2}{*}{ LAI } & \multirow[t]{2}{*}{ Thallus (mean) } & \multicolumn{4}{|c|}{ Community } & \multirow[t]{2}{*}{ Units } \\
\hline & & 3.0 & 6.3 & 8.9 & 13.8 & \\
\hline$\alpha$ & 0.064 & 0.031 & 0.049 & 0.069 & 0.072 & $\mathrm{~mol} \mathrm{O}_{2} \mathrm{~mol}^{-1}$ photon \\
\hline$I_{\text {sat }}$ & $\approx 300$ & Not sat. & Not sat. & Not sat. & Not sat. & $\mu \mathrm{mol}$ photon $\mathrm{m}^{-2} \mathrm{~s}^{-1}$ \\
\hline$I_{\mathrm{C}}$ & 22 & 67 & 99 & 94 & 175 & $\mu \mathrm{mol}$ photon $\mathrm{m}^{-2} \mathrm{~s}^{-1}$ \\
\hline$G P_{\max }$ & 7.95 & 11.5 & 17.4 & 22.0 & 23.7 & $\mu \mathrm{mol} \mathrm{O} \mathrm{O}^{-2} \mathrm{~s}^{-1}$ \\
\hline Optimal $G P_{\max }$ & - & 23.4 & 46.0 & 61.1 & 81.4 & $\mu \mathrm{mol} \mathrm{O} \mathrm{m}^{-2} \mathrm{~s}^{-1}$ \\
\hline
\end{tabular}




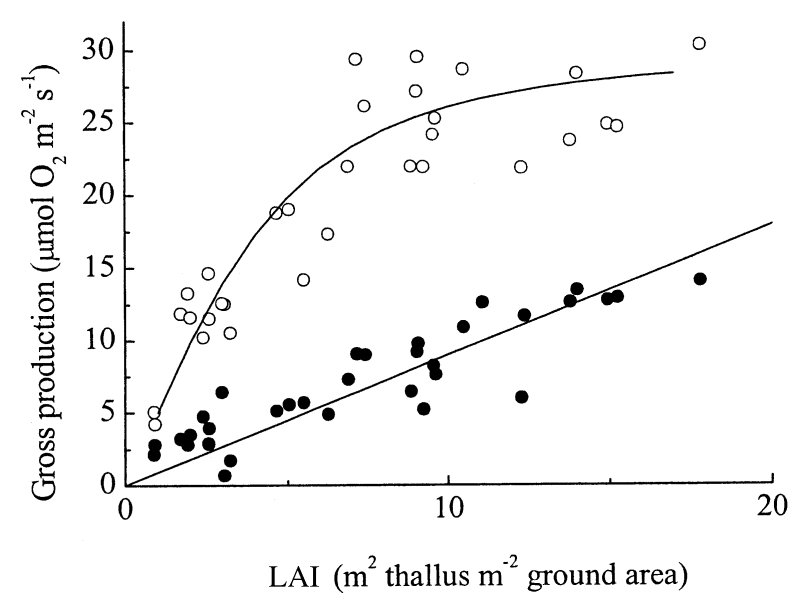

Fig. 5. Maximum gross production $(\mathrm{O})$ and respiration $(\bullet)$ in Fucus serratus communities as a function of increasing LAI. A hyperbolic curve (Eq. 1) is fitted to the data with $\beta=5.1 \pm$ $0.5 \mu \mathrm{mol} \mathrm{O} \mathrm{O}_{2} \mathrm{~m}^{-2} \mathrm{~s}^{-1} \mathrm{LAI}^{-1}$ and a maximum community gross production $G P_{\mathrm{c}, \mathrm{MAX}}=29.9 \pm 1.5 \mu \mathrm{mol} \mathrm{O} \mathrm{O}_{2} \mathrm{~m}^{-2} \mathrm{~s}^{-1}\left(\mathrm{r}^{2}=0.83\right)$. Respiration is proportional to LAI with $R_{\mathrm{C}}=0.90 \pm 0.04 \mu \mathrm{mol}$ $\mathrm{O}_{2} \mathrm{~m}^{-2} \mathrm{~s}^{-1} \mathrm{LAI}^{-1}\left(\mathrm{p}<0.0001, \mathrm{r}^{2}=0.81\right)$

among all tissue and utilised at the maximum photosynthetic efficiency $(\alpha)$ observed at low photon flux density. For an extremely dense Fucus community (i.e. LAI approaching infinity) where all incident photons are absorbed, the theoretical maximum gross production is $112 \mu \mathrm{mol} \mathrm{O} \mathrm{O}_{2} \mathrm{~m}^{-2} \mathrm{~s}^{-1}$ at a PPFD of $1600 \mu \mathrm{mol}$ photon $\mathrm{m}^{-2} \mathrm{~s}^{-1}$. Likewise, for an LAI of 18, the theoretical optimum gross production is $88 \mu \mathrm{mol} \mathrm{O}_{2} \mathrm{~m}^{-2} \mathrm{~s}^{-1}$, nearly 3 times more than the observed maximum gross production (30 $\left.\mu \mathrm{mol} \mathrm{O}_{2} \mathrm{~m}^{-2} \mathrm{~s}^{-1}\right)$ (Fig. 5). Calculated values of maximum community gross production for other densities (Table 1) demonstrate that the observed maximum gross production is between 33 and $50 \%$ of the theoretically attainable gross production.

Experimentally altering the algal canopy to a more vertical thallus orientation significantly increased maximum gross production $(22 \%)$ and maximum net production $(30 \%)$ (Table 2$)$. However, it was not possible to construct an optimal multi-layered vertical canopy structure. As a result the increase of gross

Table 2. Photosynthetic production in a more vertically structured Fucus serratus community as compared to a community of normal structure. Increases were significant $(\mathrm{p}<0.01, \mathrm{n}=11, t$-test for matched pairs $)$

\begin{tabular}{|ccc|}
\hline & \multicolumn{2}{c|}{ Increase in production } \\
& Mean (\%) & Range (\%) \\
\hline$G P_{\max }$ & 22 & $7-47$ \\
$N P_{\max }$ & 30 & $9-65$ \\
\hline
\end{tabular}

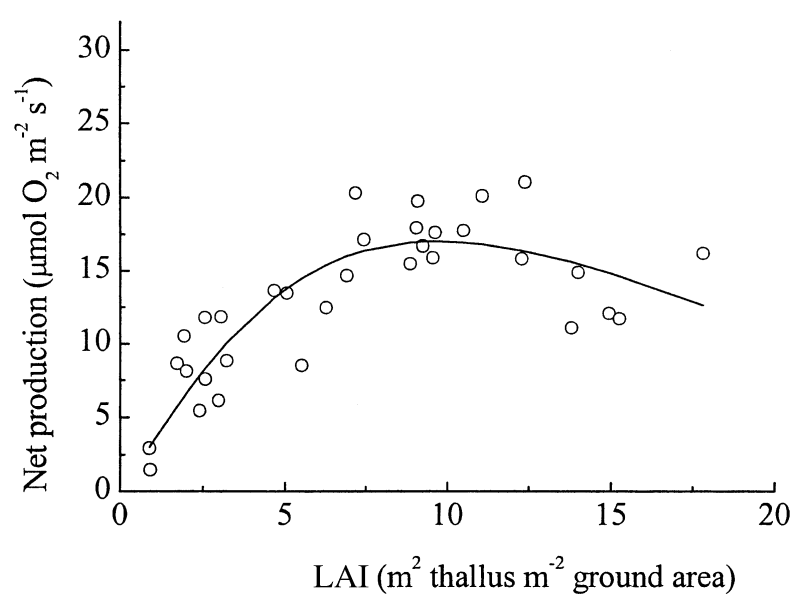

Fig. 6. Net production in Fucus serratus communities of increasing LAI. The hyperbolic relationship for net community production $\left(\mathrm{r}^{2}=0.72\right)$ was obtained by subtracting community respiration from gross community production (Fig. 5, Eq. 1)

production achieved by altering the canopy structure is an underestimation of the possible effect of light distribution in the Fucus serratus canopies.

\section{Effect of increased carbon availability}

Production of Fucus serratus communities did not change significantly when the supply rate of carbon dioxide was altered by changes of $\mathrm{pH}$ (Fig. 8). Only the $F$. serratus community with low density showed a small increase in production as $\mathrm{pH}$ was reduced from 8.4 to 8.2 (Fig. 8).

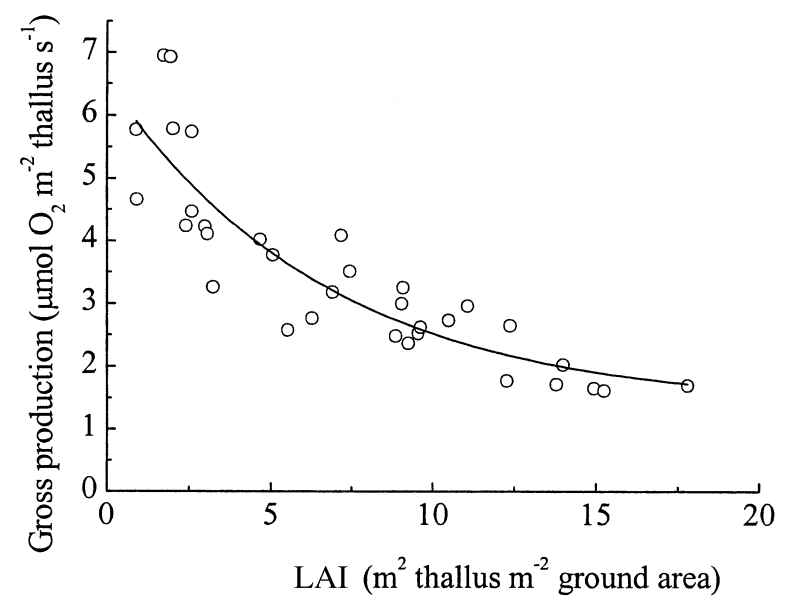

Fig. 7. Gross production per unit thallus area as a function of increasing LAI $\left(r^{2}=0.78\right)$ 


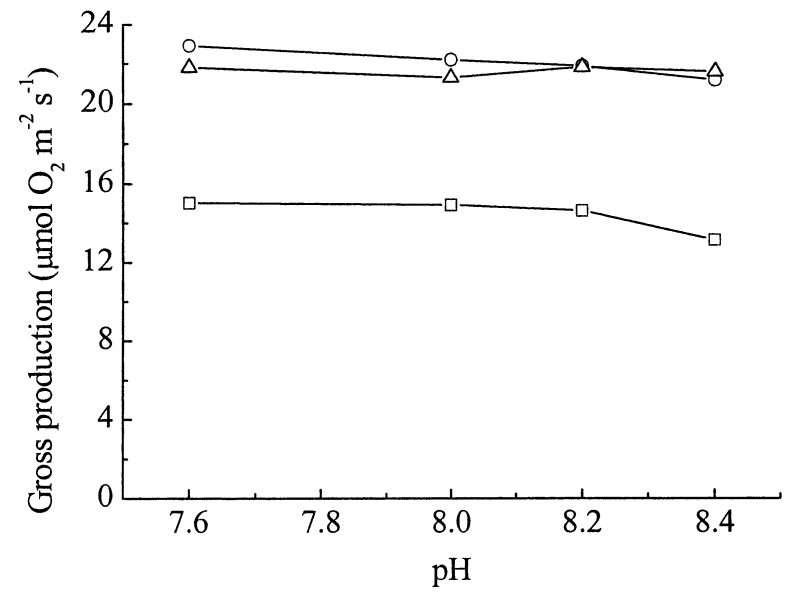

Fig. 8. Relationship between community gross production at high light and $\mathrm{pH}$ in the water in Fucus serratus communities of 3 densities. LAIs of $2.6(\square), 9.3(\Delta)$ and $12.0(0)$

\section{DISCUSSION}

\section{Production-light relationships}

Community gross production can be regarded as an integration of production rates of all photosynthetic elements in the canopy, the value of which depends on the photosynthetic characteristics of thallus parts and their local light climate (Beyschlag \& Ryel 1998). The light climate for aquatic macrophytes is variable due to the continuously changing orientation of the flexible photosynthetic tissue with water motion (Huppertz et al. 1990). Although photosynthetic tissue in the upper part of the canopy generally receives much higher photon flux densities than tissue in the lower part, waves and large-scale turbulence shift the orientation of the tissue between being perpendicular or parallel to the incoming light, thereby changing the light climate. As the variable light climate makes it difficult for aquatic species to acclimatise to the local photon flux density, this implies that only small differences in photosynthetic acclimatisation exist between different parts of the canopy. In accordance with this hypothesis, the photosynthetic efficiency in low light was insignificantly higher for thalli from the top of the Fucus serratus community compared to thalli from the bottom part of the community. A significant concurrent decline in photosynthetic production at light saturation from the top to bottom of the community is likely to be associated with increasing tissue age.

There are good optical and physiological reasons why the photosynthetic efficiency in low light should remain constant at depth in the Fucus serratus canopy. F. serratus tissue is thick and absorbs about $90 \%$ of the incident photons, so changes in pigment concentration between high light and low light environments will only alter absorptance marginally, because of strong package effects (Sand-Jensen 2000). F. vesiculosus, which has thick thalli resembling those of F. serratus, did not significantly increase pigment concentration or photon absorptance in response to reduced photon flux density at greater water depths, even though differences in the light climate for $F$. serratus were both substantial and highly predictable (Russell et al. 1998). In contrast, changes in rates of light-saturated production can be attained as shown here for F. serratus and in several earlier studies of other thick leathery algae, and such changes are established by altering the catalytic capacity of proteins and enzymes associated with carboxylation and electron flow-chain processes (Markager 1993).

Communities of Fucus serratus require much higher photon flux densities than single thallus pieces in order to reach the light compensation point and the onset of light saturation (Table 1). The light compensation point for $F$. serratus thalli averaged $22 \mu \mathrm{mol}$ photon $\mathrm{m}^{-2} \mathrm{~s}^{-1}$ in the current study, higher than 5 to $12 \mu \mathrm{mol}$ photon $\mathrm{m}^{-2} \mathrm{~s}^{-1}$ in Kirk's compilation (1983). In communities with LAIs between 3.0 and 13.8, photon flux densities of 67 to $175 \mu \mathrm{mol}$ photon $\mathrm{m}^{-2} \mathrm{~s}^{-1}$ were necessary for a positive net production, as thalli placed in the lower part of the community respired more than they photosynthesised. Furthermore, the production rate of thallus pieces fully exposed to incoming light saturated at about $300 \mu \mathrm{mol}$ photon $\mathrm{m}^{-2} \mathrm{~s}^{-1}$, whereas community production never reached full saturation even at the highest photon flux density tested (1600 $\mu \mathrm{mol}$ photon $\mathrm{m}^{-2} \mathrm{~s}^{-1}$ ).

The production-light response at low photon flux density $\left(\alpha_{c}\right)$ was also dependent on community density. The photosynthetic efficiency was low in sparse stands since a part of the light passes unutilised through the canopy. In dense canopies, all incident light was absorbed by the photosynthetic tissue, and $\alpha_{\mathrm{c}}$ values approach the quantum efficiency $(\theta)$ based on absorbed light, thus exceeding $\alpha_{t}$ values for thallus pieces that have a small loss of photons from back-scattering and transmission.

In consequence, production-light parameters for communities cannot be derived from traditional incubation methods of single leaves or thallus pieces exposed to direct incident light. In fact, community production features are strongly dependent on both community density and canopy structure.

\section{Structural effects on production in aquatic and terrestrial plant communities}

The maximum attainable gross community production of Fucus serratus in very dense communities 
(LAI of 18) exposed to $1600 \mu \mathrm{mol}$ photon $\mathrm{m}^{-2} \mathrm{~s}^{-1}$ was about $30 \mu \mathrm{mol} \mathrm{O}_{2} \mathrm{~m}^{-2} \mathrm{~s}^{-1}$, corresponding to a light utilisation efficiency of $0.018 \mathrm{~mol} \mathrm{O}_{2} \mathrm{~mol}^{-1}$ photon. The maximum gross production of most terrestrial crops, grassland and forest communities is 3 to 4 times higher and shows light utilisation efficiencies of 0.05 to $0.08 \mathrm{~mol}$ $\mathrm{O}_{2} \mathrm{~mol}^{-1}$ photon (Sand-Jensen \& Krause-Jensen 1997). The similar light utilisation efficiencies in low light of individual photosynthetic elements from aquatic and terrestrial plants suggests that differences in maximum gross production and light utilisation efficiency in high light primarily can be accounted for by structural differences between aquatic and terrestrial plant canopies.

The arrangement of leaves in terrestrial canopies makes them more efficient in converting incident photons to oxygen evolution and carbon assimilation than aquatic canopies. High efficiencies are attained in dense terrestrial canopies of broad-leaf canopies with a vertical orientation of leaves in the upper canopy and a horizontal orientation in the lower canopy (Myers et al. 1997, Smith et al. 1997) and in canopies of conifers with slender needles placed in clumps in a complex spatial pattern (Oker-Blom \& Kellomäki 1983, Ceulemans \& Saugier 1991). The relatively even distribution of light with depth in many terrestrial communities means that most leaves are exposed to low light, and can absorb and utilise photons at high efficiency on the light-limited part of the production-light response curve. As a consequence community photosynthesis continues to increase steeply up to the highest photon flux densities of 1500 to $2000 \mu \mathrm{mol}$ photon $\mathrm{m}^{-2} \mathrm{~s}^{-1}$, which is equivalent to PPFD at noon on bright summer days (Ruimy et al. 1995).

The strong curvature of the P-L curve for Fucus communities suggests that the photon flux density is not evenly distributed among thallus parts. Although gross production does not saturate at the highest photon flux density applied (1600 $\mu \mathrm{mol}$ photon $\left.\mathrm{m}^{-2} \mathrm{~s}^{-1}\right)$, there is a profound deviation from a linear productionlight relationship at photon flux densities above $200 \mu \mathrm{mol}$ photon $\mathrm{m}^{-2} \mathrm{~s}^{-1}$. The strong self-shading and suboptimal light distribution in Fucus communities is also suggested by increases in community gross production $(22 \%)$ and net production $(30 \%)$, when the canopy structure was experimentally changed to a more vertical orientation of the thalli. However, the experimental vertical orientation of the thallus pieces is far from optimal in terms of light distribution and photosynthetic utilisation as compared with multi-layered tree canopies where gradual changes of tissue orientation occur with depth in a canopy extending over many metres.

Under natural circumstances on a wave-swept shore, the thalli will continuously move, thus causing light flecks that penetrate deeper in the canopy. However, this behaviour subsequently decreases self-shading or leads to a more even distribution of light in the canopy, as the major part of the light will still be absorbed by few layers of tissue. Light flecks thus simply change the location where most of the light is absorbed. To maximise photosynthetic production, the light would still need to be evenly distributed spatially between the thallus parts.

The lower production rates of aquatic communities are often suggested to be due to light reflection from the water surface and light absorption processes in the water column that do not exist for terrestrial communities. However, this is obviously not an adequate explanation for dense communities in shallow water exposed to high photon flux densities from high solar elevations at noon for which light reflection, backscattering and water column attenuation often amount to less than $25 \%$ of the incident photon flux density. Therefore, this cannot comprehensively account for the 3- to 4 -fold difference relative to terrestrial communities. For the dense Fucus communities examined in the current study, light reflection and water column attenuation were small $(<10 \%)$ relative to plant absorptance. Doubling the incident photon flux density from 800 to $1600 \mu \mathrm{mol}$ photon $\mathrm{m}^{-2} \mathrm{~s}^{-1}$ increased community gross production by only 10 to $20 \%$, suggesting that the higher photon flux density may saturate the upper part of the Fucus community, but as it penetrates poorly to the lower part of the canopy, the photosynthetic capacity remains unutilised. A substantial effect would have been observed if light reflection and water column attenuation had severely constrained light availability and photosynthesis of the algal tissue.

\section{Carbon limitation in Fucus serratus communities}

Production rates in dense aquatic communities can also be constrained by a restricted supply rate of inorganic carbon due to the $10^{4}$-fold lower coefficients of diffusion of gases and solutes in water than of gases in air. Severe carbon limitation during intense photosynthesis in high light can lead to a strong curvature of the P-I curve resembling the one caused by inefficient light distribution in the canopy. However, carbon limitation was not responsible for the inefficient use of high photon flux densities in dense Fucus serratus communities. Fucoid species are known to use the rich supply of bicarbonate in seawater as a supplementary source of inorganic carbon to carbon dioxide (Reiskind et al. 1989). Experimental conversion of carbonate and bicarbonate in the water to the more readily usable carbon dioxide did not significantly increase community production of $F$. serratus. Moreover, since $\mathrm{pH}$ in natural seawater at air saturation is usually close to 8.2, carbon availability should have no significant effect on 
production rates in Fucus communities. Although $\mathrm{pH}$ can reach higher values than 8.4 in dense mats of algae, thereby reducing the proportion of readily usable carbon dioxide and bicarbonate, this is not likely to take place in Fucus communities that are coarsely branched and exist in wave-swept environments with high water replenishment.

Moreover, as carbon limitation, when it does take place, is more pronounced in high than in low light, a suitable canopy structure resulting in low incident photon flux densities for most tissue in the canopy should counteract the constraints of carbon limitation. Even when light is unevenly distributed between the photosynthetic tissue, however, carbon limitation will mainly restrict photosynthesis in the upper illuminated layers of tissue, while the effect will be less pronounced in the lower shaded tissue, thus decreasing the potential effect of carbon limitation in high light in communities as compared to that of single thalli.

Most marine brown and green algae are capable of using bicarbonate relatively efficiently for photosynthesis, while marine red algae and freshwater angiosperms have a much lower affinity for bicarbonate and in many cases are confined to the use of carbon dioxide alone (Maberly 1990). Further experimental manipulations of inorganic carbon supply rates are therefore needed to confirm whether it is predominantly the sub-optimal light distribution and light acclimatisation that are responsible for the low production rates in aquatic communities, relative to terrestrial communities, or whether inorganic carbon availability can significantly constrain community production for aquatic species with none or a low affinity for bicarbonate.

\section{Production and respiration at increasing community density}

The production and respiration rates observed at increasing LAI in Fucus serratus communities are in accordance with experiments and theoretical evaluations for terrestrial plant communities (de Wit et al. 1970). While gross production follows a hyperbolic relationship to LAI, respiration increases linearly, and net production consequently reaches a maximum at an intermediate LAI value of 8 to 10 . At this density, community gross production is about $25 \mu \mathrm{mol} \mathrm{O}_{2} \mathrm{~m}^{-2} \mathrm{~s}^{-1}$ and net production is about $17 \mu \mathrm{mol} \mathrm{O}_{2} \mathrm{~m}^{-2} \mathrm{~s}^{-1}$. It is obvious that single plants do not show any kind of altruistic behaviour and selective optimisation of their photosynthesis on a community basis is therefore unlikely. Since the highest $G P_{\max }$ per thallus area is attained at low community density, it implies that low community density is conducive to the maximum growth rate of single plants (Fig. 8). Furthermore, the maximum net produc- tion rate of a Fucus community exposed to a natural daynight cycle would be found at lower community densities at an LAI of 5 to 6 rather than at 8 to 10, due to mean photon flux density over the day and additional loss by respiration during nighttime. If dense Fucus communities in the field had densities of an LAI of 5 to 6 , their maximum gross production would be about $20 \mu \mathrm{mol}$ $\mathrm{O}_{2} \mathrm{~m}^{-2} \mathrm{~s}^{-1}$, which is close to the $90 \%$ percentile of gross production $\left(18 \mu \mathrm{mol} \mathrm{O}_{2} \mathrm{~m}^{-2} \mathrm{~s}^{-1}\right)$ as determined for 59 natural aquatic communities compiled by Krause-Jensen \& Sand-Jensen (1997). Thus, our experiments with $F$. serratus communities confirm not only that aquatic community production is substantially lower than terrestrial community production but also that a suboptimal distribution of light in the canopy is the main factor responsible for the low production rates.

Acknowledgements. This study was a part of T.B.'s master thesis and he would therefore like to thank all the employees at the Freshwater Biological Laboratory for a good time at the lab during the whole process. We would especially like to thank Charlotte Andersen for her help and patience during the experimental work. Thanks to Dorte Krause-Jensen, Grete Dinesen and Jan Ebdrup for constructive criticism. This study was partially financed by the EU programme BIOBASE (Contract no. MAS3-CT98-0160).

\section{LITERATURE CITED}

Barnes PW, Beyschlag W, Ryel R, Flint SD, Caldwell MM (1990) Plant competition for light analysed with a multispecies canopy model: III. Influence of canopy structure in mixtures and monocultures of wheat and wild oat. Oecologia 82:560-566

Beyschlag W, Ryel R (1998) Modelling leaf/canopy production. In: Raghavendra AS (ed) Photosynthesis, a comprehensive treatise. Cambridge University Press, Cambridge, p 305-319

Carr GM, Duthie HC, Taylor WD (1997) Models of aquatic plant productivity: a review of the factors that influence growth. Aquat Bot 59:195-215

Ceulemans RJ, Saugier B (1991) Photosynthesis. In: Raghavendra AS (ed) Physiology of trees. Wiley-Liss, New York, p 21-50

de Wit CT, Brouwer R, Penning de Vries FWT (1970) The simulation of photosynthetic systems. In: Prediction and measurement of photosynthetic productivity. Proceedings of the IBP/PP technical meeting, Trebon, 1969

Ehleringer JR, Forseth IN (1990) Diurnal leaf movements and productivity in canopies. In: Russel G, Marshall B, Jarvis PG (eds) Plant canopies: their growth, form and function. Cambridge University Press, Cambridge, p 129-142

Enriquez S, Duarte CM, Sand-Jensen K, Nielsen SL (1996) Broad-scale comparison of photosynthetic rates across phototrophic organisms. Oecologia 108:197-206

Forseth IN, Teramura AH (1986) Kudzu leaf energy budget and calculated transpiration: the influence of leaflet orientation. Ecology 67(2):564-571

Frost-Christensen H, Sand-Jensen K (1992) The quantum efficiency of photosynthesis in macroalgae and submerged angiosperms. Oecologia 91:377-384

Gaylord B, Blanchette CA, Denny MW (1994) Mechanical 
consequences of size in wave-swept algae. Ecol Monogr 64(3):287-313

Huppertz K, Hanelt D, Nultsch W (1990) Photoinhibition of photosynthesis in the marine brown alga Fucus serratus as studied in field experiments. Mar Ecol Prog Ser 66:175-182

Ishii R (1998) Leaf/canopy photosynthesis and crop productivity. In: Raghavendra AS (ed) Photosynthesis, a comprehensive treatise. Cambridge University Press, Cambridge, p 215-225

Kirk JTO (1983) Light and photosynthesis in aquatic environments. Cambridge University Press, Cambridge

Koehl MAR (1983) Seaweeds in moving water: form and mechanical function. In: Givnish TJ (ed) On the economy of plant form and function. Cambridge University Press, Cambridge, p 603-634

Krause-Jensen D, Sand-Jensen K (1998) Light attenuation and photosynthesis of aquatic plant communities. Limnol Oceanogr 43:396-407

Kuroiwa S (1970) Total photosynthesis of a foliage in relation to inclination of leaves. In: Prediction and measurement of photosynthetic productivity. Proceedings of the IBP/PP technical meeting, Trebon, 1969

Lüning K, Dring MJ (1985) Action spectra and spectral quantum yield of photosynthesis in marine macroalgae with thin and thick thalli. Mar Biol 87:119-129

Maberly SC (1990) Exogeneous sources of inorganic carbon for photosynthesis by marine macroalgae. J Phycol 26: 439-449

Madsen TV, Sand-Jensen K (1991) Photosynthetic carbon assimilation in aquatic macrophytes. Aquat Bot 41:5-40

Markager S (1993) Light absorption and quantum yield for growth in five species of marine macroalgae. J Phycol 29(1):54-63

Markager S, Sand-Jensen K (1994) The physiology and ecology of light-growth relationship in macroalgae. Prog Phycol Res 10:209-298

Myers DA, Jordan DN, Vogelmann TC (1997) Inclination of sun and shade leaves influences chloroplast light harvesting and utilization. Physiol Plant 99:395-404

Oker-Blom P, Kellomäki S (1983) Effect of grouping of foliage

Editorial responsibility: Otto Kinne (Editor),

Oldendorf/Luhe, Germany on the within-stand and within-crown light regime: Comparison of random and grouping canopy models. Agric Meteorol 28:143-155

Reiskind JB, Beer S, Bowes G (1989) Photosynthesis, photorespiration and ecophysiological interactions in marine macroalgae. Aquat Bot 34:131-152

Revsbech NP, Jørgensen BB (1986) Microelectrodes: their use in microbial ecology. Adv Microb Ecol 9:293-352

Ruimy A, Jarvis PG, Baldocchi DD, Saugier B (1995) $\mathrm{CO}_{2}$ fluxes over plant canopies and solar radiation: a review. Adv Ecol Res 26:1-68

Russel G, Jarvis PG, Monteith JL (1990) Absorbtion of radiation by canopies and stand growth. In: Russel $G$, Marshall B, Jarvis PG (eds) Plant canopies: their growth, form and function. Cambridge University Press, Cambridge, p 21-39

Russel G, Ruuskanen A, Kiirikki M (1998) Sunlight, shade and tidal night: Photoadaptation in Fucus vesiculosus L. Sarsia 83:381-386

Sand-Jensen K (1988) Photosynthetic responses of Ulva lactuca at very low light. Mar Ecol Prog Ser 50:195-201

Sand-Jensen K (2000) Økologi og Biodiversitet. Gads Forlag, Copenhagen

Sand-Jensen K, Krause-Jensen D (1997) Broad-scale comparison of photosynthesis in terrestrial and aquatic plant communities. Oikos 80:203-208

Sands PJ (1995) Modelling canopy production. II. From single-leaf photosynthetic parameters to daily canopy photosynthesis. Aust J Plant Physiol 22:603-614

Sassenrath-Cole GF (1995) Dependence of canopy light distribution on leaf and canopy structure for two cotton (Gossypium) species. Agric For Meteorol 77:55-72

Smith WK, Vogelmann TC, Delucia EH, Bell DT, Shepherd KA (1997) Leaf form and photosynthesis: do leaf structure and orientation interact to regulate internal light and carbon dioxide? Bioscience 47:785-793

Van der Bijl L, Sand-Jensen K, Hjermind AL (1989) Photosynthesis and canopy structure of a submerged plant, Potamogeton pectinatus, in a Danish lowland stream. J Ecol 77:947-962

Submitted: March 15, 2001; Accepted: October 30, 2001 Proofs received from author(s): May 17, 2002 